\title{
Počeci transplantacije bubrega u Rijeci i Hrvatskoj - sjećanje jednog sudionika
}

\section{The beginnings of kidney transplantation in Rijeka and Croatia - memories of one participant}

\author{
Petar Orlić1,2*
}

\begin{abstract}
Sažetak. Transplantacija organa jedna je od najvećih pozitivnih tekovina 20. stoljeća. Pionirsku ulogu u liječenju kroničnog zatajivanja bubrega u Hrvatskoj odigrala je Kirurška klinika KBC-a Rijeka uz suradnju s imunolozima, nefrolozima, transfuziolozima i brojnim drugim specijalistima. Prva hemodijaliza u pacijenata $s$ akutnim bubrežnim zatajivanjem učinjena je 1962. godine. U listopadu 1966. počela je redovita hemodijaliza pod vodstvom prof. dr. Jerka Zeca. To je bila osnova za program transplantacije bubrega. Ostale pripreme pod vodstvom prof. dr. Vinka Frančiškovića provodile su se tijekom nekoliko godina. Na psima smo učili operativnu tehniku transplantacije. Izučavanje kliničkih i imunoloških problema odvijalo se u okviru transplantacijske sekcije. Autor ovog teksta proveo je prvu polovicu 1969. godine na Nefrološkoj klinici pariške bolnice „Necker" pod vodstvom prof. J. Hamburgera. U dogovoru s kirurgom Michelom Lacombom prisustvovao je i prof. Frančišković jednoj transplantaciji od živog darivatelja. Temeljite su pripreme rezultirale prvom transplantacijom bubrega 30. siječnja 1971. godine. Majčin bubreg presađen je 34-godišnjem pacijentu. Pacijent je umro 14,5 godina kasnije s funkcionirajućim bubregom. Prvi bubreg umrle osobe presađen je 15. svibnja 1972. godine. Darivatelj je bila žena čija je smrt utvrđena na temelju zastoja srca. Pacijent je umro šest mjeseci kasnije od milijarne tuberkuloze. Usprkos želji da se što više koristi umrla osoba kao darivatelj, tijekom dugog razdoblja veći dio naše aktivnosti činile su transplantacije od živog darivatelja, zbog pritiska mnogih pacijenata iz drugih krajeva Hrvatske i ostalih republika bivše države. Mali broj bubrega od umrle osobe davali smo pacijentima na listi čekanja prema pravilima odabira. Tako je, primjerice, više od 20 pacijenata iz Slovenije dobilo bubreg u Rijeci. Nesebično smo pomagali i ostalim centrima u početku njihove transplantacijske aktivnosti. Započinjanje transplantacijskog programa dovelo je do značajnog napretka riječke i hrvatske medicine.
\end{abstract}

Ključne riječi: povijest; transplantacija bubrega; završni stadij bubrežne insuficijencije
${ }^{1}$ Klinika za urologiju, Klinički bolnički centar Rijeka, Rijeka, Hrvatska

${ }^{2}$ Katedra za urologiju, Medicinski fakultet Rijeka, Sveučilište u Rijeci, Rijeka, Hrvatska

\begin{abstract}
Organ transplantation is one of the greatest achievements of the 20th century. In Croatia the pioneering role in the treatment of end-stage renal disease was done by Department of Surgery in the Clinical Hospital Rijeka which cooperated closely with immunologists, nephrologists, transfusiologists and other specialists. The first hemodialysis in patient with acute renal insufficiency was done in 1962. The chronic dialysis began in October 1966 under the leadership of prof. Jerko Zec. Establishement of the dialysis was the basis for the program of kidney transplantation. The other preparations during several years were under leadership of prof. Vinko Frančišković. We learned the operative technics on dogs. Clinical and immunological problems were debated on regularly meetings. The author of this text stayed the first six months in 1969 at the Department of Nephrology in "Necker" hospital in Paris. He arranged with the transplant surgeon Michel Lacombe a visit of professor Frančišković to Paris to see a kidney transplantation from living donor. Solid preparations resulted in the first kidney transplantation performed at the January $30^{\text {th }} 1971$. The mother gave her kidney to 34 -year old son. The recipient died 14,5 year after transplantation with functional transplant. The first cadaveric transplantion was performed at the May $15^{\text {th }} 1972$. The donor was a woman injured in traffic accident. The diagnosis of death was based on cardiac arrest. The patient died after 6 months from miliary tuberculosis. Contrary to our wish to use cadaveric donor as much as possible, during many years we performed more transplants from living donor due to pressure of many patients from other
\end{abstract}

\author{
*Dopisni autor: \\ Prof. dr. sc. Petar Orlić, dr. med. \\ Klinika za urologiju Medicinskog fakulteta \\ Sveučilišta u Rijeci, Klinički bolnički centar \\ Rijeka, Tome Strižića 3, 51000 Rijeka \\ E-mail: petar.orlic11@gmail.com
}

http://hrcak.srce.hr/medicina 
regions of Croatia and others republics of Yugoslavia. Small number of cadaveric kidneys we gave to patients on waiting list toward rules of selection. For example, more than 20 patients from Slovenia received new kidney in Rijeka. We helped unselfishly to other centers in the beginning of their transplant activity. The beginning of transplantation programme undoubtedly has significant positive impact on development of medicine in the Rijeka and Croatia.

Key words: end stage renal disease; history; kidney transplantation

Francuska i Pariz bili su predvodnici u transplantacijskoj medicini u eksperimentalnoj fazi, ali i u razdoblju njezine kliničke primjene. Shodno tome iz cijele Europe, Sjeverne i Južne Amerike, pa tako i iz Rijeke, dolazili su mnogobrojni liječnici na edukaciju iz ovog multidisciplinarnog području medicine. Riječki transplantacijski program predstavljao je nastavak francuske transplantacijske škole.

\section{UVOD}

Na Kirurškoj klinici bolnice „Dr. Zdravko Kučić“ na Sušaku počela su u kolovozu 1967. raditi dva nova specijalizanta iz kirurgije (dr. Andrej Gudović i dr. Petar Orlić). Dogovorno su izabrali odjel, je- dan urološki, a drugi traumatološki. Vrlo brzo su se snašli, jer su poznavali osoblje iz vremena vježbi iz kirurgije i liječničkog staža. Za nekoliko mjeseci su počeli dežurati. Budući da u službi za transfuziju krvi nije bilo dosta osoblja, dežurali su za njih, a kad nije bilo posla, pomagali su mlađem dežurnom kirurgu.

Nepunu godinu dana prije njihova dolaska, ujesen 1966. godine, započela je redovita hemodijaliza za pacijente $s$ terminalnim zatajenjem bubrega (slika 1). Radom je rukovodio dr. Jerko Zec, voditelj odjela za torakalnu kirurgiju. Istovremeno su se mogla dijalizirati dva pacijenta. Dijaliza je trajala 12 sati. $U$ to vrijeme koristio se Kiilov dijalizator.

\section{EKSPERIMENTALNA KIRURGIJA NA SUŠAKU}

Kod prijama na Kiruršku kliniku zatekli su već uhodanu aktivnost na eksperimentalnoj kirurgiji na psima. Cilj tog rada bilo je učenje kirurške tehnike transplantacije bubrega i operacije na otvorenom srcu. Prostorija se nalazila u suterenu istočnog dijela zgrade. Smještaj pasa bio je skroman. Zahvati su se vršili u općoj anesteziji. Psi su preživljavali, jer se izvodila nefrektomija i auto-

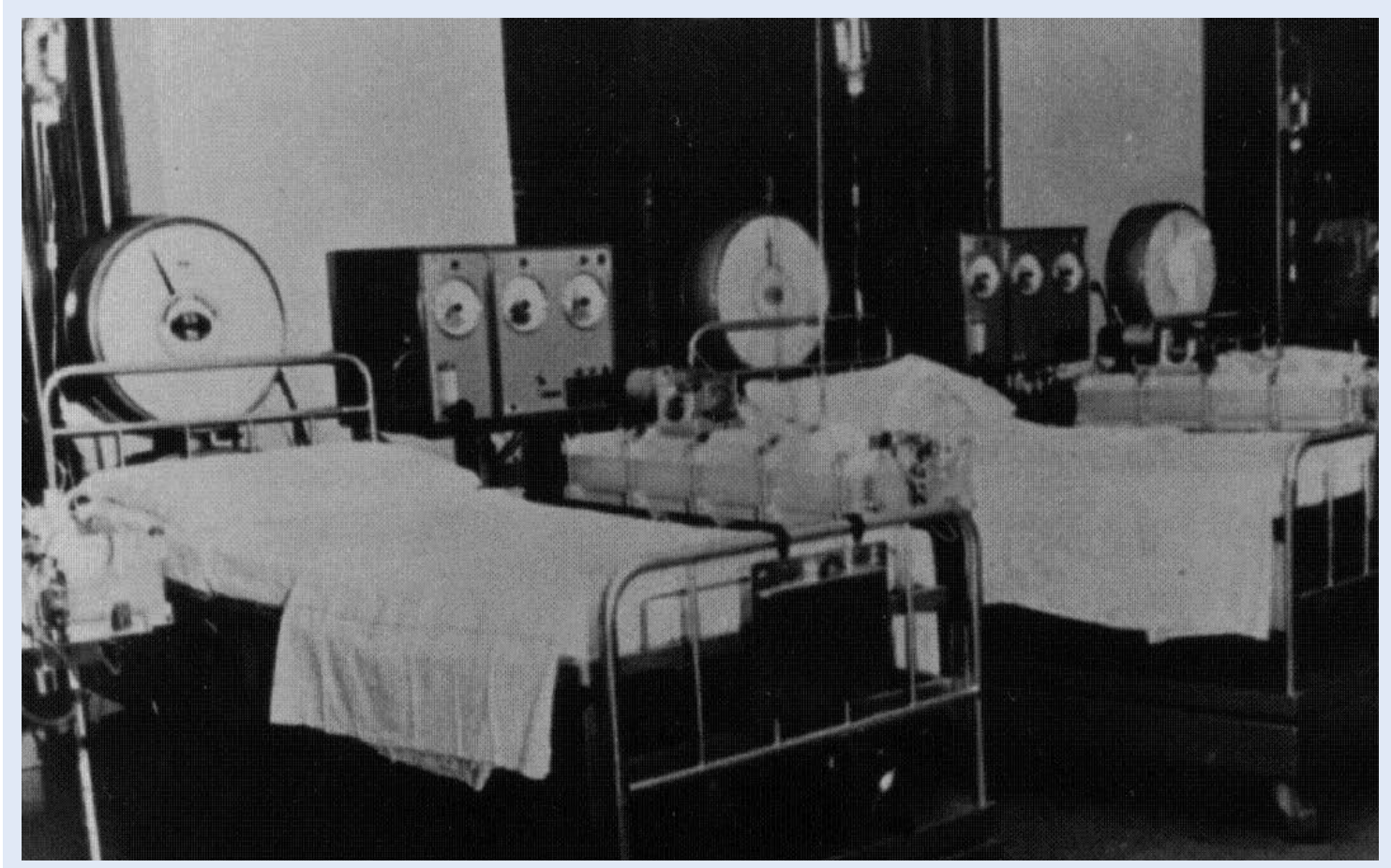

Slika 1. Prvi odjel za hemodijalizu u tadašnjoj bolnici „Dr. Zdravko Kučić“ u Rijeci (Sušaku), fotografirano sredinom šezdesetih godina 20. stoljeća. 
transplantacija nakon perfuzije. U pasa je prepariranje bilo lagano, jer se anatomske strukture vrlo dobro vide, a venska stijenka je jako tanka pa se kroz nju vidi krv. Ubrzo nakon njihovog dolaska ujesen 1967. izvršen je prvi operativni zahvat na srcu zbog otvora na septumu.

\section{EDUKACIJA U FRANCUSKOJ}

U proljeće 1968. godine predstojnik kirurške klinike doc. dr. Vinko Frančišković (slika 2) pozvao je mlađeg specijalizanta iz kirurgije, autora ovog teksta, sredinom radnog vremena u svoj ured. Pokazao mu je članak u časopisu Presse médicale o iskustvu s transplantacijom bubrega na 52 pacijenta u pariškoj bolnici „Necker“" Rekao je da nam se pruža mogućnost korištenja francuske stipendije. Zamolio ga je da to prihvati, što je on, nakon kraćeg razmišljanja, i učinio. Pariz je već upoznao u kolovozu 1963. tijekom studentske razmjene na četvrtoj godini studija, te je otputovao posljednjeg dana prosinca 1968., ostavivši kod kuće suprugu i kćer od nepunih šest mjeseci.

\section{Kratka povijest bolnice „Necker“}

Bolnica „Necker“ razvila se iz hospicija koji je 1778. godine osnovala Suzanne Necker, supruga ministra financija, uz pomoć kralja Luja XVI. Početkom 19. stoljeća počinju se tamo liječiti pacijenti s mokraćnim kamencima. Unutar istog kruga nalazi se i dječja bolnica „Enfants malades“.

\section{Uloga bolnica „Necker“ i „Foche“ u razvoju transplantacije bubrega}

Ranih 50-ih pojavili su se pokušaji transplantacije bubrega u bolnicama „Necker" i „Foche“ od smaknutih osoba na giljotini. Svi su ti pokušaji bili neuspješni, jer nije bilo imunosupresije.

Urolog René Küss (1913. - 2006.) iz bolnice „Foche" inaugurirao je kiruršku tehniku usađivanja bubrega u malu zdjelicu koja se održala do danas $^{2}$. Na čelu nefrološke klinike u „Neckeru“ bio je Jean Hamburger (1909. - 1992.), jedan od vodećih nefrologa tog vremena ${ }^{3}$. U Badnjoj noći 1952. izveo je kirurški tim u „Neckeru“ pod vodstvom Louisa Michona transplantaciju majčinog bubrega sinu na njezin zahtjev4 ${ }^{4}$. Mladić je izgubio solitarni bubreg zbog ozljede pri padu sa skele. Bubreg je dobro funkcionirao tri tjedna, nakon toga je odbačen.

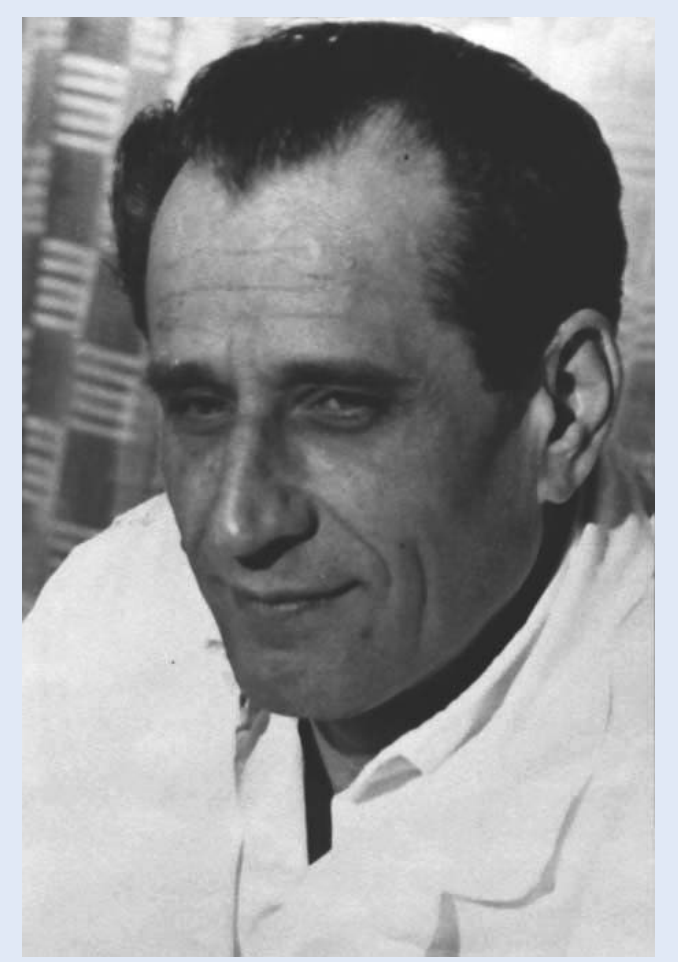

Slika 2. Prof. dr. Vinko Frančišković, predstojnik Klinike za kirurgiju u tadašnjoj bolnici „Dr. Zdravko Kučić" u Rijeci (Sušaku).

Aktivnost Parižana nije prošla nezapaženo. Zbog toga su neki pohrlili u Pariz da nešto korisno nauče. Najpoznatiji među njima bio je nefrolog John Merrill (1917. - 1984.) iz Bostona, koji je 1952. proveo u "Neckeru“ kao studijsku godinu, želeći se usavršiti u transplantacijskoj imunologiji. Nakon Merrillovog povratka kući Hamburger i Merrill nastavili su surađivati u nadi da će jednog dana moći uspješno presaditi bubrege. U Bostonu je 1954. izvršena transplantacija bubrega između jednojajčanih blizanaca ${ }^{5}$.

Ujesen 1958. prof. Hamburger pomogao je hematologu prof. Georgeu Mathéu u liječenju ozračenih fizičara iz nuklearnog instituta u Vinči kod Beograda ${ }^{6}$. To mu je iskustvo dobro došlo u primjeni doziranog zračenja $u$ imunosupresiji pacijenta prije transplantacije bubrega iduće godine. U Bostonu je transplantacija od nejednojajčanih blizanaca izvršena u siječnju, a u Parizu koncem lipnja $1959^{7,8}$.

Zanimljivo je spomenuti da je Hamburger sedam godina prije Daussetova otkrića prvog HLA antigena pretpostavio da takav sustav postoji i da će poslužiti za odabir između darivatelja i primatelja? 


\section{Dolazak u Pariz}

Dodijeljen je asistentu dr. Michelu Leskiju, koji je bio zadužen za kliničko praćenje pacijenata nakon transplantacije bubrega. Već je uvečer tog prvog dana učinjena transplantacija bubrega od umrle osobe. Dr. Leski mu je preporučio da ne ostaje na zahvatu, budući da se još nije navikao na kasno vraćanje kući. Bubreg je primila mlada pacijentica, vrlo razgovorna i vedra osoba, s kojom su se još više puta vidjeli na kontrolnim pregledima. Vrijedna spomena je činjenica da je prije zahvata provela 22 mjeseca na hemodijalizi preko Scribnerovog arterijsko-venskog shunta na zapešću.

\section{Aktivnost na odjelu}

Za vrijeme boravka našeg gosta izvršeno je 15 transplantacija bubrega. Pacijente su redovito obilazili u viziti, a po potrebi i češće. Velike liste veličine C2 sa svim rezultatima laboratorijskih pretraga i ostalim podacima visjele su na stranici kreveta i bile uvijek dostupne. Pomoću tih lista, u koje su i gosti upisivali podatke, pažljivo su pratili klinički tijek pacijenta. Slične liste se i do današnjeg dana koriste na Klinici za urologiju u praćenju transplantiranih pacijenata.

Među pacijentima upoznao je djevojčicu iz Zagreba, koja se zbog insuficijencije bubrega s obitelji preselila u Pariz i primila majčin bubreg. Pohađala je osnovnu školu. Kod dolaska nije znala jezik, ali je s vremenom postala najbolja učenica u razredu.

Srijedom u 11 sati održavao se sastanak s patolozima. Redovito su dolazili i pedijatrijski nefrolozi. Liječnici s odjela dali bi kratki klinički prikaz, na što bi se nadovezali patolozi prikazom materijala dobivenog biopsijom bubrega. Slika mikroskopskih preparata projicirala se na veliko platno poput onog u kinu. Oni su već tada često pretragu nadopunjavali imunofluorescencijom depozita $u$ bubregu. Jedan od patologa bio je prof. dr. Jean Berger (1930. - 2011.) koji je otkrio IgA depozite (Bergerova bolest - IgA nefropatija).

\section{Operateri i kirurški aspekti transplantacije bubrega}

Transplantaciju sa živog darivatelja izvodila su naizmjenično dva operatera: urolog Jean Auvert iz bolnice „Créteil“ operirao je u „Neckeru“, a vaskularni kirurg Michel Lacombe u bolnici „Beaujon“ u Clichyju, u sjevernom dijelu Pariza. Ta mu je činjenica išla u prilog, jer se dr. Michel Leski zadržao po nekoliko sati, do buđenja pacijenta iz anestezije. To su vrijeme provodili u razgovoru o transplantaciji. Presađivanje bubrega od živog darivatelja odvijalo se u dvije operacijske dvorane. U prvoj se uzimao bubreg. Taj zahvat u pravilu traje nešto dulje nego sličan zahvat vađenja bolesnog bubrega. Važno je bilo dobiti što bolji bubreg uz očuvanje anatomije. Optimalnom količinom infuzije postizalo se dobro lučenje mokraće koje ide u prilog dobroj početnoj funkciji bubrega ${ }^{10}$. Nakon vađenja bubreg se perfundirao hladnom tekućinom. Tim se postupkom ispirala krv, a hlađenjem se smanjivao negativni učinak odsustva cirkulacije. U primatelja se odstranio vlastiti bubreg, a nakon toga se bubreg usadio u ilijačnu jamu. Lijevi se bubreg darivatelja obično stavljao na desnu stranu pacijenta i obrnuto. Renalna vena anastomozirala se termino-lateralno na ilijačnu venu, a arterija termino-terminalno na unutarnju ilijačnu arteriju, čiji se periferni kraj prije toga podvezao. Kontinuitet urinarnog puta uspostavio bi se anastomozom uretera transplantata na ureter pacijenta. U slučaju ureteralnog refluksa ili megauretera odstranio se uz vlastiti bubreg i čitav ureter primatelja te usadio ureter u mokraćni mjehur.

\section{Seoba klinike u novu zgradu}

U proljeće 1969. godine došlo je preseljenja odjela u novu zgradu u kojoj se već nalazila knjižnica, laboratoriji i ranije spomenuta velika predavaonica. Novi je odjel pružio pacijentima i osoblju znatno bolje uvjete smještaja i rada. Operacijske dvorane služile su samo za potrebe transplantacije. Izolacijske sobe za čuvanje pacijenta nakon zahvata nalazile su se u sklopu tog dijela objekta. Način ulaženja u trakt bio je isti onom kod ulaza u operacijsku dvoranu. Čitav se prostor sterilizirao ultraljubičastim svjetlom.

\section{Indikacijski sastanci na Urološkoj klinici bolnice „Necker“-}

Urološka klinika nalazila se u susjednom dijelu nove zgrade. Za upoznavanje urologije dobro su mu došli njihovi indikacijski sastanci subotom u 10 sati. Znalački ih je u opuštenoj atmosferi sa smislom za humor vodio predstojnik prof. Roger 
Couvelaire (1903. - 1986.). Bio je jedan od pionira u upotrebi crijevnih transplantata u urologiji.

\section{Tečaj o usavršavanju iz transplantacije}

Već je ranije spomenuto da je literatura o transplantaciji bila oskudna. Zbog toga mu je dobro došao tečaj o usavršavanju u transplantaciji koji se te godine prvi puta održao u Lyonu. Grupu stipendista vozio je grčki urolog Platon, stipendist na urološkoj klinici. Tečaj je pripremila grupa kliničara i imunologa predvođena nefrologom prof. Julesom Traegerom. Predavanja i rad u manjim grupama bili su jako dobri. Francuska je tada bila vodeća europska zemlja u transplantaciji, tako da je bilo gostiju iz više zemalja. Na tečaj je opet pošao 1971. s prof. Frančiškovićem. Tamo su našli profesora Mira Košaka iz Ljubljane. Na večeri je spomenuta ideja o osnivanju Jugotransplanta. U Lyonu se našao opet nakon Domovinskog rata. U razgovoru s nefrologom iz Grenoblea doznao je o pozitivnom iskustvu s lijekom mikofenolat-mofetilom, što je ubrzalo njegovu nabavku.

\section{Actualitées néphrologiques}

U proljeće 1969. godine održan je tradicionalni znanstveni skup Actualitées néphrologiques. Među ostalima došao je i prof. John Merrill iz Bostona. Guy Alexandre iz Louvaina u Belgiji govorio je o njihovu iskustvu na polju transplantacije bubrega od umrle osobe. Naš je stipendist pozorno slušao, jer za čitavo vrijeme boravka nije uspio prisustvovati eksplantaciji bubrega od umrle osobe. Glavni je uzrok tome bila činjenica što „Necker" nema odjela na kojem se liječe potencijalni darivatelji organa. Nekoliko puta je proveo večer šećući Parizom i telefonom pratio pripremu eksplantacije, ali bi se to uvijek protegnulo u noć. Dvije godine poslije našeg početka transplantacije bubrega kolege Andrej Gudović i Duje Vukas proveli su tri mjeseca u Aarhusu u Danskoj i uspjeli skupiti dovoljno saznanja o uzimanju bubrega od umrle osobe.

\section{Posjet prof. Frančiškovića Parizu}

U dogovoru s profesorom Michelom Lacombom dogovoren je dolazak prof. Frančiškovića na transplantaciju bubrega od živog darivatelja te je njegov dolazak i ostvaren sredinom mjeseca lipnja 1969. godine.

\section{TRANSPLANTACIJSKA SEKCIJA}

S obzirom na važnost imunologije u kliničkoj transplantaciji, prof. Frančiškoviću je bilo jasno da mora uspostaviti suradnju sa Zavodom za fiziologiju Medicinskog fakulteta u Rijeci. Ta se suradnja formalizirala u Transplantacijskoj sekciji. Predsjednici sekcije bili su prof. Vinko Frančišković i prof. Šime Vlahović, a tajnik dr. Daniel Rukavina, asistent na Zavodu za fiziologiju. Iz bolnice „Dr. Zdravko Kučić" u radu sekcije sudjelovali su, pored kirurga, anesteziolozi, nefrolozi, transfuziolozi, bakteriolog i voditelj biokemijskog laboratorija te sudski medicinar iz Zavoda za sudsku medicinu.

Prvi sastanak održao se 29. prosinca 1969. godine. Dogovorili smo se da se sastanci održavaju svakog drugog ponedjeljka u 17 sati u Zavodu za fiziologiju. Posljednji sastanak održali smo 22. prosinca 1971. Pojedini članovi su prema dogovoru iznosili svoj mogući doprinos iz svoje specijalnosti. Susreti na sastancima pridonijeli su boljoj suradnji nakon početka transplantacije.

Laboratorij za transfuziju krvi surađivao je u učenju tipizacije HLA antigena s prof. Matejom Plavšak iz Kliničnog centra u Ljubljani. Nekoliko puta nam se pridružio i prof. dr. Vlatko Silobrčić iz Imunološkog zavoda u Zagrebu, koji je proizvodio antilimfocitni globulin.

\section{PRVA TRANSPLANTACIJA BUBREGA U RIJEC I HRVATSKOJ}

U Jugoslaviji su se vršile pripreme za transplantaciju bubrega u Beogradu, Zagrebu, Ljubljani i Rijeci. Jednog dana polovinom travnja 1970. rekao nam je primarijus Branko Fink, zamjenik prof. Frančiškovića, da je u Novom listu pročitao vijest o transplantaciji bubrega u Ljubljani. Primatelj je nažalost umro od infekcije nakon dva tjedna.

Kliničnom centru u Ljubljani trebalo je puno vremena da se oporavi i nastavi program transplantacije. Rijeka je kao najmlađi fakultet u zemlji izgledala na prvi pogled kao najslabiji „trkač“, ali je iznenadila svojom kompetencijom, koja je bila rezultat dugotrajne i temeljite pripreme i entuzijazma.

Prva transplantacija bubrega izvršena je u Rijeci u subotu 30. siječnja 1971. godine (slika 3, 4). 


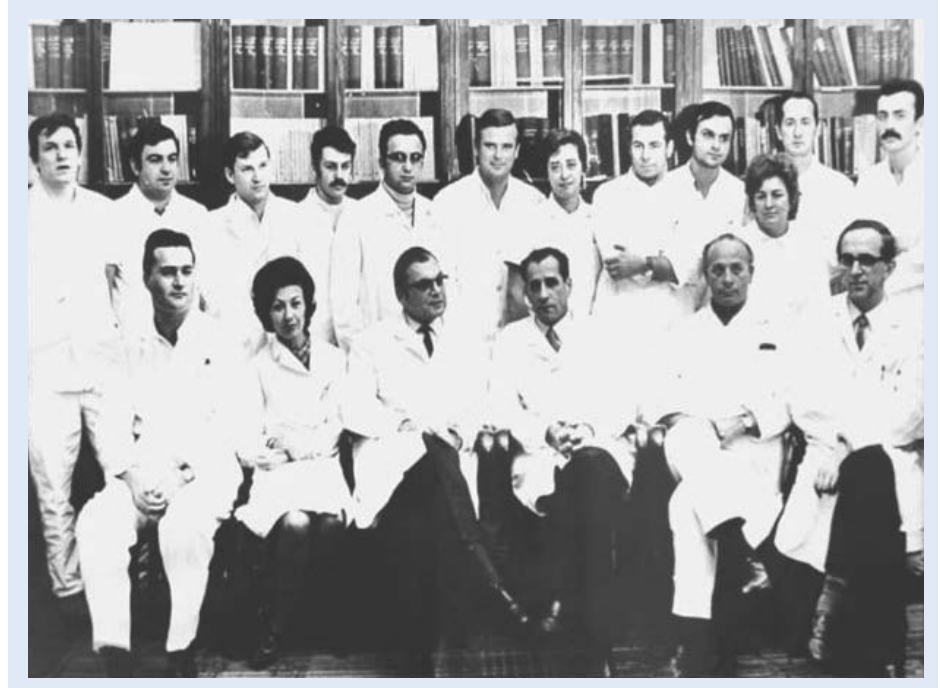

Slika 3. Multidisciplinarni tim na čelu s prof. Vinkom Frančiškovićem koji je učinio prvu transplantaciju bubrega 1971. godine.

Sjede (gledajući s lijeve strane): dr. Petar Orlić (kirurgija), dr. Ksenija Vujaklija-Stipanović (transfuziologija), prof. dr. Šime Vlahović (fiziologija), prof. dr. Vinko Frančišković (kirurgija), dr. Tomislav Tićac (kirurgija), dr. Jerko Zec (kirurgija, hemodijaliza). Stoje (gledajući s lijeve strane): dr. Giampaolo Velčić (kirurgija), dr. Miomir Zelić (kirurgija), dr. Damir Dimec (kirurgija), dr. Nikola Gržalja (mikrobiologija), dr. Daniel Rukavina (fiziologija), dr. Ante Šepić (kirurgija), dr. Alenka Suzanić (anesteziologija), dr. Vjerislav Peterković (kirurgija), dr. Duje Vukas (kirurgija), dr. Branimir Budisavljević (kirurgija), dr. Andrej Gudović (kirurgija). Na slici nedostaju voditeljica anesteziološke službe dr. Vlasta Strižić i voditelj biokemijskog laboratorija mr. Davor Smokvina.

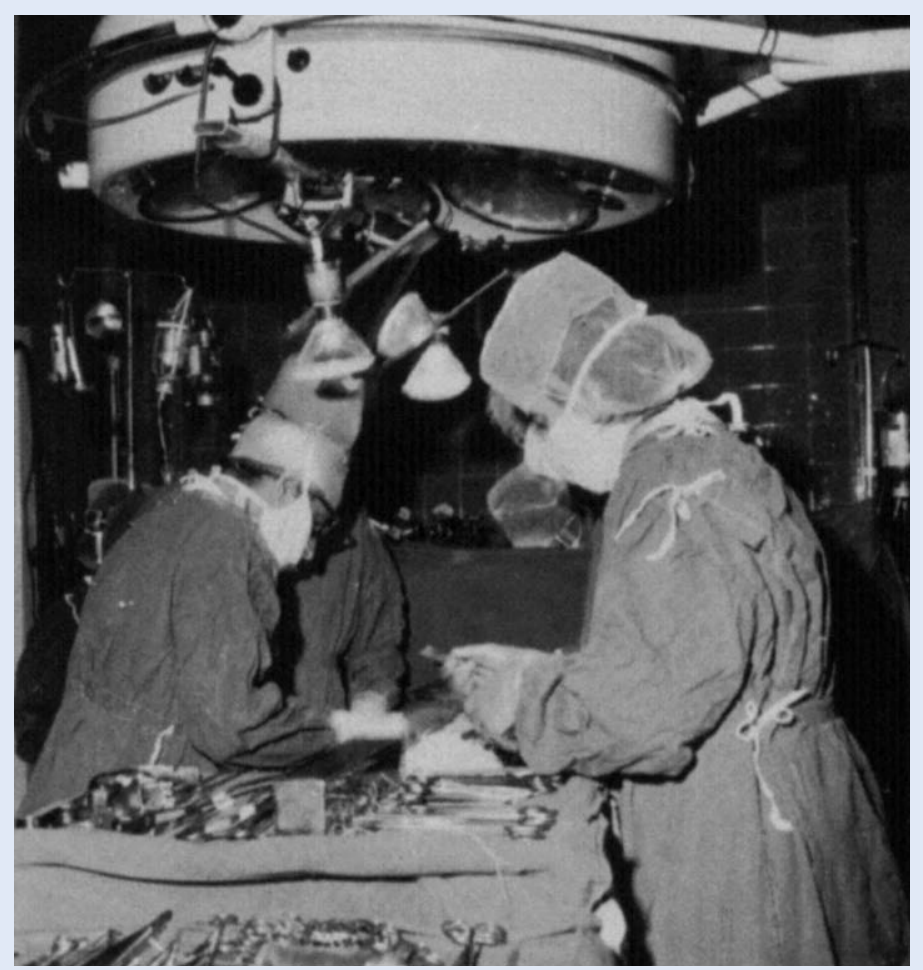

Slika 4. Detalj iz operacijske sale tijekom prve transplantacije, prof. dr. Vinko Frančišković prvi s lijeve strane.
Primatelj bubrega bio je 34-godišnji pacijent iz Pule. Uzrok zatajenja bubrega bio je kronični glomerulonefritis. Darivatelj bubrega bila je 49-godišnja pacijentova majka. Zahvat se odvijao istovremeno u dvije operacijske dvorane. Ljevostranu nefrektomiju darivateljici izvršili su dr. Vjerislav Peterković, prof. dr. Jerko Zec, dr. Andrej Gudović i instrumentar Josip Dijaković. Perfuziju bubrega Perfudexom i koordinaciju u radu oba tima vršili su dr. Petar Orlić i dr. Miomir Zelić. Nakon nefrektomije vlastitog desnog bubrega majčin su bubreg usadili prof. dr. Vinko Frančišković, dr. Branimir Budisavljević, dr. Damir Dimec i instrumentarka Albina Zoretić. Renalna vena anastomozirana je termino-lateralno na venu ilijaku eksternu. Renalna arterija anastomozirana je termino-terminalno na arteriju ilijaku internu. Vaskularne anastomoze potrajale su 43 minute. Bubreg je odmah preuzeo funkciju. Kontinuitet urinarnog puta uspostavljen je ureteroureteralnom anastomozom uz nefrostomiju ${ }^{11}$. Oporavak je bio brz, a pacijent je postigao dobru kvalitetu života (slika 5).

Prema dogovoru naš je stipendist u bolnici proveo tri dana i vodio brigu o pacijentu. Primatelj je nakon 14,5 godina umro od tumora jetre uz dobru funkciju bubrega. Do kraja 1971. godine učinili smo još pet transplantacija.

Prvu transplantaciju od umrle osobe učinili smo 15. svibnja 1972. Darivatelj je bila žena koja je umrla nekoliko dana nakon prometne nesreće. Pacijent je umro nakon 6 mjeseci od milijarne tuberkuloze. Na obdukciji darivatelja bubrega nađene su tuberkulozne promjene.

Da bi što bolje upoznao kolege s problematikom transplantacije stipendist je ostavio svoje bilješke iz Pariza u sobi mlađeg dežurnog kirurga. Osim toga, uskoro smo počeli održavati sastanke posvećene transplantaciji svake subote nakon profesorove vizite. Sredinom jeseni uveli smo praksu da svakog novog primatelja bubrega vodi drugi kolega. To je sve pridonijelo boljem poznavanju problematike transplantacije bubrega. 


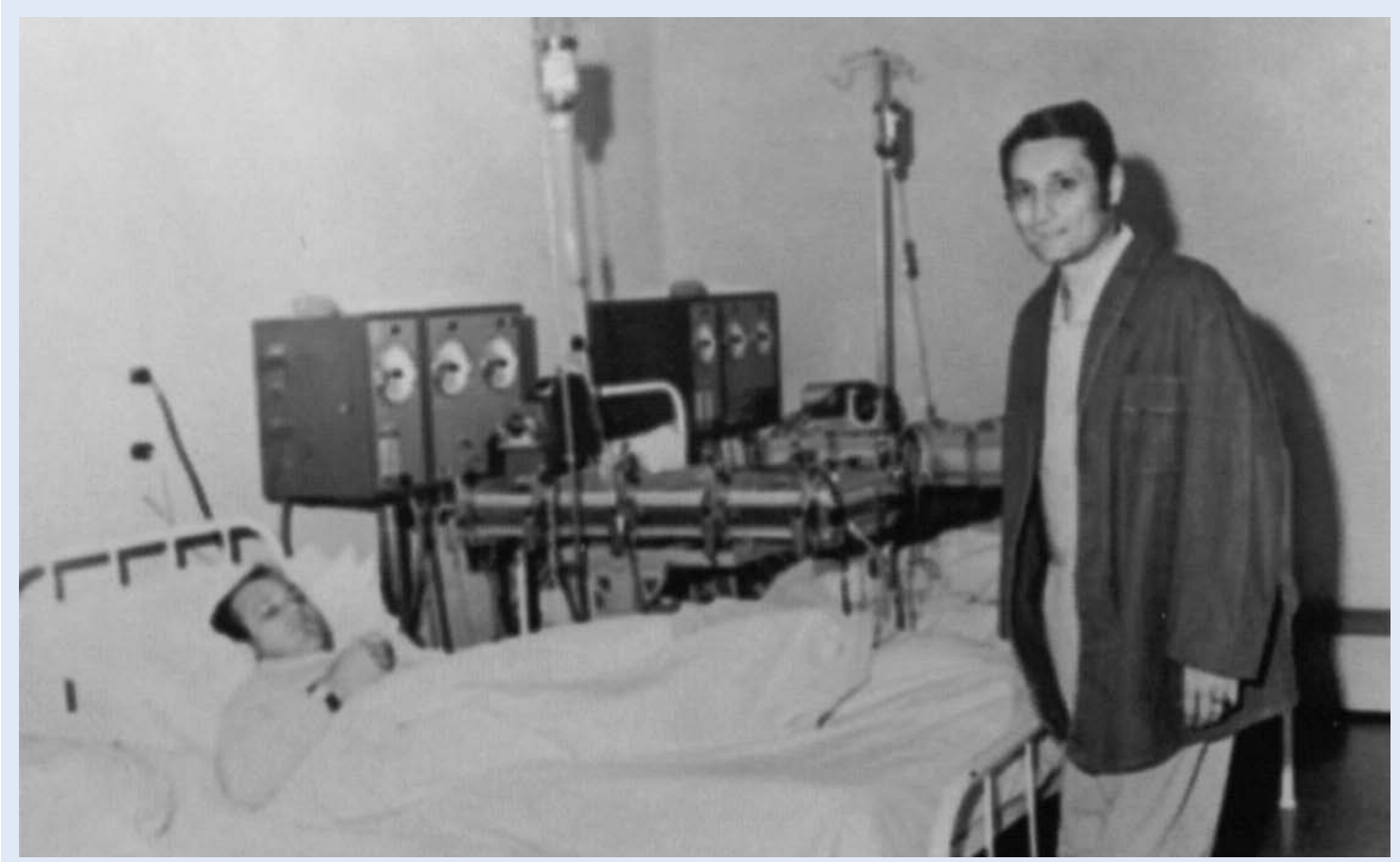

Slika 5. Prvi pacijent s transplantiranim bubregom u Rijeci posjećuje drugog pacijenta na hemodijalizi i ohrabruje ga da slijedi njegov primjer.

\section{PRIPREMA DARIVATELJA I PRIMATELJA} U POČETNOM RAZDOBLJU

\section{Priprema pacijenta za transplantaciju bubrega}

Redovitom dijalizom nastojali smo postići što bolje stanje u trenutku odlaska na transplantaciju. U obradi primatelja obvezna je bila mikcijska cistografija koja je ponekad otkrivala vezikoureteralni refluks. U slučaju tuberkuloze u anamnezi darivatelja ili primatelja kroz neko vrijeme smo davali izoniazid. Stomatološkim, otorinolaringološkim, ginekološkim i drugim pregledima nastojalo se pronaći žarišta infekcije i sanirati ih prije početka imunosupresije. U slučaju povišenih jetrenih nalaza u pacijenta s hepatitisom čekalo se do normalizacije nalaza.

\section{Neposredna priprema pacijenta za transplantaciju}

Posljednja dijaliza vršila se dan prije transplantacije. Naš je stipendist zastupao mišljenje da to bude dva dana ranije, kao što su prakticirali u Parizu. Na taj način je pacijent išao na zahvat bolje hidriran. Kod kadaverične transplantacije duljina dijalize prije zahvata ovisila je o stanju pacijenta i koncentraciji kalija. U slučaju niskog hematokrita davala se transfuzija krvi.
Prva transplantacija bubrega u Rijeci i Hrvatskoj učinjena je 30. siječnja 1971. godine pod vodstvom prof. dr. Vinka Frančiškovića. Bila je to kruna napora ljudi različitih specijalnosti koji su udružili svoje znanje i sposobnosti i tako okrenuli novu stranicu u medicini, ne samo Rijeke i Hrvatske, već i mnogo šire.

\section{RAZVOJ RIJEKE KAO GLAVNOG TRANSPLANTACIJSKOG CENTRA}

Uspješan početak imao je za posljedicu dolazak brojnih pacijenata sa živim srodnim darivateljem iz drugih krajeva Hrvatske i drugih republika bivše države. Tome je pridonijelo i započinjanje transplantacija bubrega od umrle osobe, učinjene u manjeg broja pacijenata, jer smo pozivali pacijente prema kompatibilnosti u ABO sustavu krvnih grupa i HLA. Uvjet za usađivanje bubrega bila je negativna križna proba između limfocita darivatelja i seruma primatelja. Ako je više primatelja jednako odgovaralo, kliničar bi odabrao prema stupnju hitnosti.

\section{Broj transplantiranih pacijenata}

Do 31. siječnja 1974. godine presadili smo 40 bubrega, 34 od živog srodnog darivatelja i 6 od 
Tablica 1. Broj transplantacija bubrega od 1971. do 1974. godine

\begin{tabular}{|l|c|c|c|}
\hline \multicolumn{1}{|c|}{ Razdoblje } & \multicolumn{3}{c|}{ Broj transplantacija } \\
\cline { 2 - 4 } & Živi & Kadaverični & Ukupno \\
\hline 30. 1. 1971. - 30. 1. 1972. & 7 & - & 7 \\
\hline 30. 1. 1972. - 30. 1. 1973. & 8 & 4 & 12 \\
\hline 30. 1. 1973. - 30. 1. 1974. & 19 & 2 & 40 \\
\hline Ukupno & 34 & 6 & 21 \\
\hline
\end{tabular}

Tablica 2. Geografska pripadnost transplantiranih pacijenata (1971. - 1974.) u SFRJ-u

\begin{tabular}{|l|c|c|c|}
\hline \multicolumn{1}{|c|}{ Geografska pripadnost } & \multicolumn{3}{c|}{ Darivatelj } \\
\cline { 2 - 4 } Naše područje (Hrvatsko primorje, Istra, Gorski kotar) & Živi & Kadaverični & Ukupno \\
\hline Ostali dijelovi Hrvatske & 7 & 4 & $11(27,5 \%)$ \\
\hline Ostale republike & 11 & 1 & $12(30 \%)$ \\
\hline Ukupno & 16 & 1 & $17(42,5 \%)$ \\
\hline
\end{tabular}

Tablica 3. Geografska pripadnost transplantiranih pacijenata po republikama i pokrajinama SFRJ-a (1971. - 1990.)

\begin{tabular}{|l|c|c|c|}
\hline \multicolumn{1}{|c|}{ Republika - pokrajina } & Živi darivatelj & Kadaver & Ukupno \\
\hline Bosna i Hercegovina & 38 & 10 & $48(10,23 \%)$ \\
\hline Crna Gora & 14 & 0 & $14(2,98 \%)$ \\
\hline Hrvatska & 98 & 140 & $238(50,75 \%)$ \\
\hline Kosovo & 13 & 0 & $13(2,78 \%)$ \\
\hline Makedonija & 6 & 0 & $6(1,28 \%)$ \\
\hline Slovenija & 7 & 17 & $24(5,12 \%)$ \\
\hline Srbija & 75 & 16 & $91(19,40 \%)$ \\
\hline Vojvodina & 30 & 5 & $35(7,46 \%)$ \\
\hline UKUPNO & 281 & 188 & 469 \\
\hline
\end{tabular}

mrtvog darivatelja ${ }^{12}$. Osim broja zahvata po godinama, iznosimo i podatke o geografskoj pripadnosti pacijenata (tablica 1 i 2). Do ljeta 1990. učinili smo ukupno 460 transplantacija, 276 (60 \%) od živog darivatelja i 184 (40\%) od umrle osobe (tablica 3).

\section{Predavanje o transplantaciji bubrega}

Predavanje u Liječničkom domu u Zagrebu u organizaciji Kirurške sekcije Hrvatskoga liječničkog zbora održano je koncem 1971. godine. Predavaonica je bila ispunjena do posljednjeg mjesta. Predavanja su održali predstojnik prof. dr. Vinko Frančišković, voditelj dijalize prof. dr. Jerko Zec, liječnica iz tipizacijske službe dr. Eja Miculinić i prof. Vlatko Silobrčić iz Imunološkog zavoda. Naš stipendist nije imao predavanje, ali je bio tamo za slučaj da bude pitanja o kliničkom tijeku transplantiranih pacijenata.

\section{Imunosupresija}

U vrijeme našeg početka najčešće korišten imunosupresiv bio je azatioprin, antimetabolit koji inhibira T limfocite, ali i sve stanice koje se intenzivno dijele. Važne nuspojave su leukopenija i hepatotoksičnost. Leukopenija među pacijentima tumači se kao posljedica selektivnog hipersplenizma na neutrofilne leukocite. Ako nakon stimulacije kortikosteroidom ne bi došlo do dovoljnog povećanja neutrofila, pacijent je bio kandidat za splenektomiju. Splenektomija je izvršena u 12 pacijenata, bilo zbog opisanog stanja ili nehotične 
splenektomije uz lijevu nefrektomiju. Grupa splenektomiranih pacijenata pokazala je najbolje preživljavanje transplantata. U nekim se centrima gotovo rutinski vršila splenektomija.

Kortikosteroide smo rutinski davali pacijentima nakon dobivanja bubrega od umrle osobe. Pacijentima s bubregom od živog darivatelja dali bismo kortikosteroid uz akutnu krizu odbacivanja, a nakon toga nastavili dugotrajno. Od polovice 1982. počeli smo sistematski davati kortikostroide svim pacijentima.

Antilimfocitni serum (globulin, ALG) davali smo u početku intramuskularno, a kasnije u infuziji.

\section{Transplantacija sa živim darivateljem}

Prihvatili smo stav da ne bi trebalo uzimati darivatelje starije od 55 godina. Ipak, u nekoliko slučajeva prihvatili smo i starije osobe, no tek nakon ponovljenih pregleda i konzultacija, koje su pokazale da postoji velika vjerojatnost dobrog ishoda po darivatelja. Radilo se uvijek o roditeljima, a mogućnosti za transplantaciju s drugim živim ili kadaveričnim darivateljem nije bilo. Naš najstariji živi darivatelj imao je 69, a najmlađi 19 godina ${ }^{12}$.

Nesrodne žive darivatelje, u pravilu, nismo prihvaćali, no učinili smo to u dva slučaja. Prvi je bio tzv. free kidney. Radilo se o medicinskoj sestri s tegobama zbog pelvične ektopije desnog bubrega. Tegobe su bile takve da je ona čvrsto odlučila riješiti se svog bubrega. Obradom se našlo manji bubreg s tri arterije i tri vene. Primatelj je bio mladić koji je majčin bubreg odbacio za 6 mjeseci. Zahvat je bio tehnički zahtjevan, ali je transplantacija uspješno učinjena. Bubreg je preživio 20 godina. Nakon toga je mladić dobio bubreg od umrle osobe. Drugi je pacijent, otac našeg kolege, dobio bubreg od svoje HLA identične supruge.

\section{Normalan tijek nakon transplantacije bubrega}

Vjerojatno nema u medicini situacije koja se viđa kod pacijenata s povoljnim tijekom nakon transplantacije bubrega ${ }^{12}$. Pacijent koji je godinama bolovao od progresivne bolesti koja ide svom kraju ili trajnoj dijalizi doživi u jednom danu potpuni obrat. Prva promjena je obilna diureza koja može doseći više litara u prvim danima. Klirens kreatinina je u početku na $50 \%$ vrijednosti, a zbog kompenzatorne hiperplazije može nakon nekog vremena postići 75 do $100 \%$ vrijednosti normale za oba bubrega. Neposredno nakon transplantacije postoji lagana proteinurija koja je posljedica ishemijske lezije za vrijeme zahvata, no ona brzo nestaje. Dva do tri mjeseca nakon transplantacije nestaje anemija uzrokovana kroničnom bubrežnom insuficijencijom.

\section{Promjena strukture primatelja i darivatelja bubrega kroz $\mathbf{4 0}$ godina}

$U$ početku našeg bavljenja renalnom insuficijencijom pacijenti su bili mlađe životne dobi. To je imalo svoje dobre i loše strane. Dobro je u tome bilo što su imali kvalitetne krvne žile za pristup krvotoku zbog dijalize i moguće transplantacije te zdrave vitalne organe, osim bolesnih bubrega. Loša strana njihove mladosti bio je jaki imuni odgovor nakon transplantacije. Zbog anemije povremeno su dobivali transfuziju krvi, što je imalo kod nekih za posljedicu pojavu protutijela na HLA antigene. Naše mogućnosti imunosupresije bile su skromne. To je imalo za posljedicu jaču manifestaciju procesa odbacivanja. Darivatelji su također bili mlađi, i srodni i umrli.

\section{Darivatelji organa s nekucajućim srcem}

Kada smo započeli transplantaciju bubrega kao izvor organa bili su nam dominantno na raspolaganju živi darivatelji, a od umrlih samo darivatelji s nekucajućim srcem. Uzimanju bubrega pristupali smo nakon utvrđivanja smrti na temelju zastoja srca. Smrt mozga počela se utvrđivati kasnih 70-ih, a prvi zakon o regulaciji te problematike pojavio se u ljeto 1980. Mogućnost korištenja pogodnijih darivatelja dočekali smo s olakšanjem i, poput ostalih, ubrzo zaboravili na darivatelje $s$ nekucajućim srcem. Sve veća potreba za organima potakla je transplantacijske kirurge u nekim centrima da se vrate korištenju organa od darivatelja s nekucajućim srcem.

Glavni je problem u korištenju darivatelja s nekucajućim srcem nezaobilazna duža topla ishemija, dakle prestanak cirkulacije krvi na tjelesnoj temperaturi, što dovodi u pitanje vitalnost organa. U međuvremenu su se razvile tehnike hlađenja organa perfuzijom in situ, čime se prekida topla ishemija. Ranije su se bubrezi mogli ohladiti tek nakon nefrektomije. Svoje iskustvo s perfuzijom in situ opisali smo u radu prezentiranom u Varšavi $1998 .{ }^{13}$ 
Tablica 4. Kriteriji za prihvaćanje darivatelja s nekucajućim srcem

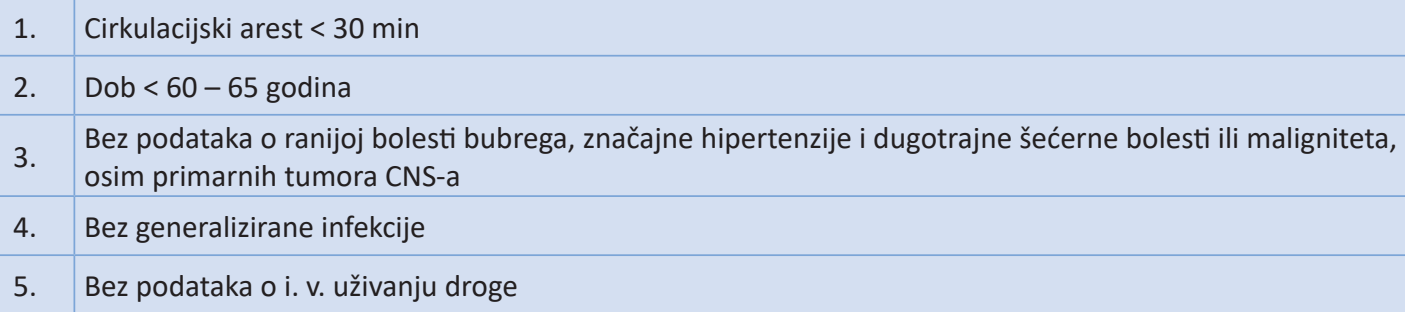

Legenda: CNS - centralni nervni sustav

Tablica 5. Kategorije darivatelja nakon zastoja srca
I. Dovezen mrtav
II. Neuspjeli CPR
III. U očekivanju srčanog aresta
IV. Zastoj srca uz smrt mozga

U svijetu je opisano uzimanje i drugih organa od kontroliranih darivatelja s nekucajućim srcem: jetre, pankreasa i pluća ${ }^{14-16}$.

Kasnije je došlo do višegodišnjeg prekida zakonskog pokrića za uzimanje organa darivateljima s nekucajućim srcem. Koliko nam je poznato, u drugim transplantacijskim centrima u Hrvatskoj nije se koristilo darivatelje s nekucajućim srcem. Na kongresu Hrvatskog društva za transplantacijsku medicinu koncem 2018. u Zagrebu bilo je nekoliko predavanja kolega iz zapadne Europe o iskustvu korištenja darivatelja s nekucajućim srcem.

Potrebno je poštovati kriterije za prihvaćanje darivatelja s nekucajućim srcem (tablica 4), a u tablici 5 prikazane su kategorije darivatelja nakon zastoja srca.

\section{ZAKONSKA REGULATIVA TRANSPLANTACIJE}

$U$ vrijeme prve transplantacije nije bilo zakona koji bi to regulirao. U praksi je to značilo da živi srodni darivatelji mogu darivati svoje bubrege, a da se mrtvim darivateljima smrt može dokazati na temelju zastoja srca. Takvo je stanje potrajalo gotovo 10 godina, do ljeta 1980. godine kada je prihvaćen Zakon o transplantaciji u svrhu liječenja. Prema članku 4. Zakona o uzimanju i presađivanju dijelova ljudskog tijela u svrhu liječenja, dijelovi tijela s umrle osobe mogu se uzimati radi presađivanja ako se umrla osoba za života nije tome izričito protivila, odnosno ako se tome nisu izričito usprotivili roditelj, bračni drug ili punoljetno dijete umrlog.

Budući da je u zapadnoj Europi pojam smrti mozga bio poznat već kasnih pedesetih, imao je za posljedicu uzimanje organa u ranim šezdesetim godinama 20. stoljeća. Naši neurolozi, neurokirurzi i anesteziolozi počeli su na konkretnim slučajevima vježbati ispitivanje elemenata smrti mozga. U praksi je osamdesetih godina pozitivan odgovor obitelji na upit o darivanju bubrega bio oko $30 \%$. Isto je toliko bilo medicinskih kontraindikacija za uzimanje bubrega i protivljenja obitelji. Na inicijativu pacijenata na dijalizi pokrenuta je kampanja da se izmijeni zakon u smislu pretpostavljenog pristanka, tj. da se organi mogu uzeti ako se punoljetna osoba za života ne izjasni da se protivi davanju organa. Do promjene zakona došlo je tek koncem 1988. godine. Članak 2. govori o promjeni članka 4. u Zakonu iz 1980. godine i glasi: „Dijelovi tijela s umrle osobe uzimaju se radi presađivanja ako se umrla osoba za života nije tome izričito pismeno protivila. Dijelovi tijela maloljetne umrle osobe kao i osobe koja je bila duševno bolesna mogu se uzeti radi presađivanja samo uz pristanak njenih roditelja ili bračnog druga ili punoljetnog djeteta ili staratelja."

Pitanje utvrđivanja smrti potencijalnih darivatelja organa regulirao je Pravilnik o pobližim medicinskim kriterijima i načinu utvrđivanja nastanka smrti osobe od koje se mogu uzimati dijelovi tijela radi presađivanja u svrhe liječenja koji je izišao koncem 1982.

Formiranjem KBC-a Rijeka i uključivanjem većeg broja liječnika u liječenje potencijalnih darivatelja organa dovelo je do potrebe da se i unutar KBC-a donese dokument koji bi to regulirao. Dana 20. srpnja 1984. donesen je na sjednici Radničkog sa- 
vjeta Pravilnik o postupku s osobama od kojih se zbog nastanka smrti mogu uzimati dijelovi ljudskog tijela radi presađivanja u svrhu liječenja.

\section{JUGOSLAVENSKA ZAJEDNICA ZA DIJALIZU I TRANSPLANTACIJU - JUGOTRANSPLANT}

Po ugledu na organizacije koje organiziraju transplantacijsku aktivnost u jednoj zemlji (Francetransplant) ili grupi susjednih zemalja (Eurotransplant, Scandiatransplant) i mi smo u bivšoj državi 1973. godine osnovali Jugotransplant. Razmjena bubrega bila je minimalna zbog skromne aktivnosti ostalih centara. Tijekom 5 godina (1973. - 1978.) transplantirali smo 41 bubreg od umrle osobe i 111 od živog darivatelja. Većinu bubrega smo sami dobili u našoj ustanovi. Sedam bubrega upućeno nam je iz drugih centara: dva iz Sarajeva, jedan iz Zagreba, tri iz Milana i jedan iz Engleske, posredstvom Scandiatransplanta (u perfuzeru).

Nesebično smo pomagali ostalim centrima $u$ izvođenju prvih transplantacija bubrega. U Zagrebu se to dogodilo u listopadu 1973. godine. Miješane ekipe izvele su transplantaciju bubrega HLA identične sestre bolesnom bratu. Naš je stipendist ostao u Zagrebu 10 dana i uveo dr. Sigmunda Thunea u problematiku vođenja pacijenta. Ekipa iz Rijeke pomogla je još u prvoj transplantaciji u Sarajevu 1974. i Skopju 1977. godine. U Sarajevu smo pomagali još više godina nakon što su prekinuli suradnju s njihovim urolozima.

Jugotransplant je ipak pridonio afirmaciji transplantacije kao metode liječenja zatajivanja bubrega i početku utvrđivanja smrti na temelju smrti mozga. Pridonio je i donošenju zakona o transplantaciji u Hrvatskoj 1980. i kasnije, u ostalim republikama, te donošenju pravilnika o utvrđivanju smrti 1982. godine.

\section{ZANIMLJIVOSTI IZ POČETNOG RAZDOBLJA}

1. Želja profesora Frančiškovića bila je da se prva transplantacija izvede u miru, bez znanja javnosti. Zamolio je novinarku Novog lista, koja je vodila zdravstvenu rubriku, da o događaju piše tek nakon što se odigra. Problem je bila činjenica da Novi list nije izlazio nedjeljom. Posljedica bi bila da vijest objave ostali listovi ranije od lokalnog glasila. Rezultat toga bio je da je u subotnjem No-

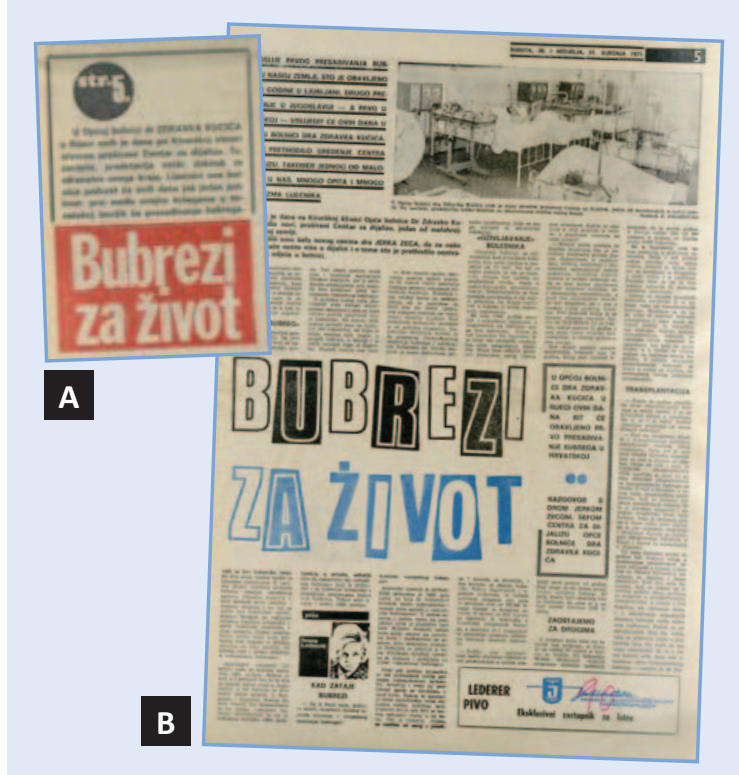

Slika 6. Novi list je na sam dan transplantacije na naslovnici najavio prvu transplantaciju bubrega (A) uz članak na petoj stranici (B).

vom listu osvanuo naslov na prvoj stranici „Bubrezi za život", gdje se nagovijestila prva transplantacija bubrega (slika 6). To je jako razljutilo profesora Frančiškovića i poremetilo odnose s novinarkom.

2. Radilo se o crnoputom Sudancu koji je došao studirati medicinu u Niš. Tijekom boravka otkrivena mu je renalna insuficijencija, a kako Niš u to vrijeme nije imao redovite dijalize, došao je na dijalizu u Rijeku. Ujesen 1984. dobio je bubreg umrle osobe. Darivatelj je doživio srčani arest nakon što se nepripremljen izložio tjelesnom naporu. Uz reanimaciju je prebačen $u$ jedinicu intenzivnog liječenja gdje je idućeg dana umro. Obdukcija je pokazala da se radilo o infarktu miokarda. Transplantat je preuzeo funkciju. Pacijent je završio studij medicine i specijalizaciju iz interne medicine. Nakon nekog vremena pošao je posjetiti obitelj u južnom Sudanu. Povratak se oduljio zbog građanskog rata i ostao je bez lijekova. Kada se konačno vratio, bubreg je ipak dobro funkcionirao. Poznato je da Afroamerikanci imaju jači imuni odgovor od bijelaca. U našeg pacijenta moguće je da je imuni odgovor bio slabiji kao posljedica kimerizma nakon transplantacije ${ }^{17}$.

3. Gastrointestinalna krvarenja nakon transplantacije bubrega bila su velik problem početkom 70-ih godina. Glavnina krvarenja je bila iz njegova gornjeg dijela, a činila su $7 \%$ ukupnog mortalite- 
ta ${ }^{18}$. Uvođenjem antagonista histaminskih $\mathrm{H} 2$ receptora (cimetidin) stanje se popravilo. U terapijske svrhe smo ga počeli koristiti 1978. godine, a idućih godina i profilaktički. Pojava ranitidina još je više unaprijedila profilaksu i liječenje ulkusne bolesti. Zbog visoke smrtnosti uz krvarenje iz peptičkog ulkusa prihvatili smo da se svaki pacijent s ulkusom podvrgne operaciji prije transplantacije ${ }^{21}$. Tako je 6 pacijenata podvrgnuto vagotomiji i piloroplastici. Profilaksu cimetidinom primila su 204 pacijenta, a nakon toga je u profilaksu uveden ranitidin.

Izjava o sukobu interesa: Autori izjavljuju kako ne postoji sukob interesa.

\section{LITERATURA}

1. Hamburger J, Crosnier J, Dormont J, Réveillaud RJ, Hors $\mathrm{JH}$, Alsina J. Homotransplantation rénale humaine. Résultats personnels chez 52 malades. I. Technique et résultats d' ensemble. Presse méd 1965;73:2793-8.

2. Küss R, Teinturier J, Milliez P. Quelques essais de greffes de rein chez l'homme. Mem Acad Chir (France) 1951;77: 755-64.

3. Legendre Ch, Kreis H. A tribute to Jean Hamburger's contribution to organ transplantation. Am J Transplant 2010;10:2392-5.

4. Michon L, Hamburger J, Oeconomos $\mathrm{N}$ et al. Une tentative de transplantation rénale chez l'homme: aspects médicaux et biologiques. Presse méd 1953;61:1419-23.

5. Murray JE, Merrill JP, Harrison JH. Renal transplantation in identical twins. Surg Forum 1955;6:432-6.

6. Mathé $G$, Jammet $H$, Pendic B, Schwarzenberg I, Duplan $J F$, Maupin B et al. Transfusions and grafts of homologous bone marrow in humans after accidental high dosage irradiation. Rev Fr Etud Clin Biol 1959;4:226-38.

7. Merrill JP, Murray JE, Harrison JH. Successful homotransplantation of human kidney betweeen non-identical twins. N Engl J Med 1960;262:1251-60.
8. Hamburger J, Vaysse J, Crosnier J, Tubiana M, Lalanne $\mathrm{CM}$, Antoine $B$ et al. Transplantation d'un rein entre jumeaux non monozygotes après irradiation du receveur. Bon functionnement au $4^{\mathrm{e}}$ mois. Presse méd 1959;67:1771-2.

9. Hamburger J. Note préliminaire sur les greffes rénales. Journal d'Urologie 1947;53:563-7.

10. Dubernard JM, Long $\mathrm{H}$, Georg JL, Banssillon G, Blitz $\mathrm{M}$, Bomel $\mathrm{J}$ et al. Study of the function of a renal transplant during removal from the donor. J Urol Nephrol (Paris) 1974;80:814-23.

11. Frančišković $\mathrm{V}$, Vlahović Š, Zec J, Orlić P, Peterković V. Transplantacija bubrega - prikaz jednog slučaja. Lijec Vjesn 1971;93:849-57.

12. Frančišković $\mathrm{V}$, Čohar F, Gudović $A$, Orlić $P$, Smokvina $D$, Strižić $V$ et al. Iskustva nakon 40 transplantacija bubrega. Lijec Vjesn 1975;97:323-32.

13. Orlić $P$, Zelić $M$, Petrošić $N$, Maričić $A$, Zambeli $M$, Bačić $G$ et al. Use of non-heart-beating donors: preliminary experience with perfusion in situ. Transplant Proc 1999;31:2097-8.

14. Casavilla A, Ramirez C, Shapiro R,Nghiem D, Miracle K, Fung $\mathrm{JJ}$ et al. Liver and kidney transplantation from nonheart-beating donors: the Pitsburgh experience. Transplant Proc 1995;27:710-12.

15. D'Alessandro AM, Odorico JS, Knechtle SJ, Becker YT, Hoffman RM, Kalayoglu M et al. Simultaneous pancreaskidney (SPK) transplantation from controlled non-heartbeating donors (NHBDs). Cell Transplantation 2000;9: 889-93.

16. Steen S, Sjöberg T, Pierre L, Liao Q, Eriksson L, Algotsson L. Transplantation of lungs from a non-heart-beating donors. Lancet 2001;357:825-9.

17. Starzl TE, Demetris AJ, Trucco M, Zeevi A, Ramos H, Terasaki $P$ et al. Chimerism and donor-specific nonreactivity 27 to 29 years after kidney transplantation. Transplantation 1993;55:1272-7.

18. Gurland HJ, Brunner FP, Dehn H, Hārlen H, Parsons FM, Schārer K. Combined report on regular dialysis and transplantation in Europe. In: Moorhead JF, Baillod RA, Mion C (eds). Proceedings of the Tenth Congress of the Eur. Dial. Transplant Assoc., Vienna: Pitman medical, 1973;17-62.

19. Wray RC Jr, Wangensteen SL Results of vagotomy and pyloroplasty for peptic ulcer. Surgery 1969;66:502-5. 